\title{
Verbum
}

Volume 13 | Issue 1

Article 14

$12-1-2015$

\section{What do you want to be when you grow up?}

Kathleen Donovan

St. John Fisher University

Follow this and additional works at: https://fisherpub.sjf.edu/verbum

C. Part of the Political Science Commons How has open access to Fisher Digital Publications benefited you?

\section{Recommended Citation}

Donovan, Kathleen (2015) "What do you want to be when you grow up?," Verbum: Vol. 13: Iss. 1, Article 14. Available at: https://fisherpub.sjf.edu/verbum/vol13/iss1/14

This document is posted at https://fisherpub.sjf.edu/verbum/vol13/iss1/14 and is brought to you for free and open access by Fisher Digital Publications at . For more information, please contact fisherpub@sjf.edu. 


\title{
What do you want to be when you grow up?
}

\author{
Abstract \\ In lieu of an abstract, below is the essay's first paragraph. \\ There is no doubt in my mind that most if not all students have been asked this question; some as early \\ as pre-school, likely more often as graduation creeps closer. Though I must admit to asking this question \\ of others, it is usually tongue-in-cheek, as I have come to dislike it for a number of reasons. In particular, I \\ take issue with three assumptions implicit to the question: 1) you already know what you want to be; 2) \\ that there is only one thing that you can or will be; and 3) there is some age at which you are "grown up" \\ and have everything figured out, including the answers to 1 and 2. Let's start with the first one, and \\ everything that's wrong with it.
}




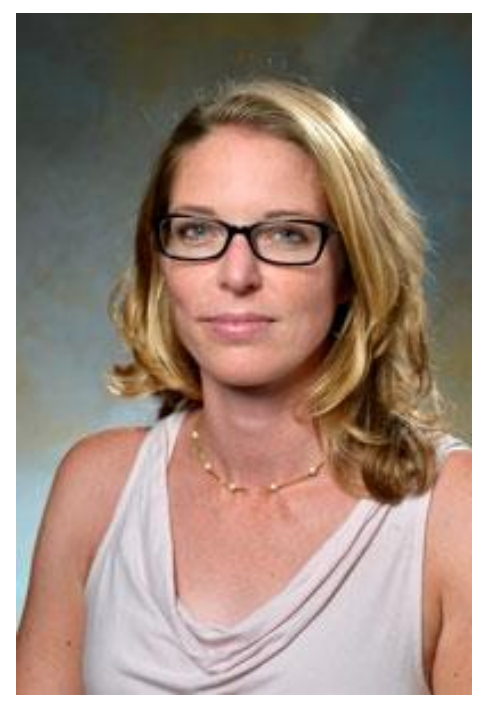

Dr. Kathleen Donovan

\section{What do you want to be when you grow up?}

There is no doubt in my mind that most if not all students have been asked this question; some as early as pre-school, likely more often as graduation creeps closer. Though I must admit to asking this question of others, it is usually tongue-in-cheek, as I have come to dislike it for a number of reasons. In particular, I take issue with three assumptions implicit to the question: 1) you already know what you want to be; 2) that there is only one thing that you can or will be; and 3) there is some age at which you are "grown up" and have everything figured out, including the answers to 1 and 2. Let's start with the first one, and everything that's wrong with it.

\section{Assumption 1: You already know what you want to be.}

Some of you actually do know what you want to be, and that is wonderful. Others have been told what you're going to be. That's not ideal - unless it happens to coincide with your own desires but at least it quells the existential crisis. The rest of you have at best some vague idea or ideas about what you might like to do. If you're still reading, that last one probably describes you.

First of all, that's okay.

Second of all, yes, you will have to figure out something to do after graduation. But it doesn't have to be and in all probability will not be what you are going to do or be for the rest of your working life. You have just spent 16 years being told what to do and when to do it. This may be 
the first time you get to truly decide what's next. You should use this time to try something new, or live somewhere else, but mostly follow your gut.

My gut tells me that, finally given the first real chance to shape one's life, a lot of people are afraid of making the wrong decision. But if it pays the bills and doesn't make you miserable, it's never the wrong decision. It only gets you a step closer to figuring out what you do like. In many instances it's difficult to know whether or how much you will like a job or not until you do it for a while. Don't you think that's a lot to ask a person that they know what they will be doing for 30,40 , or 50 years before ever even doing it? I do.

I even find it a lot to ask a person to know that the job they want exists at all. At an early age we are taught the prototypical ones: teacher, doctor, pilot. We know these exist. Yet there are thousands of different kinds of jobs, many of which you haven't heard of or, if you have, don't really know what it entails. More than once I have thought to myself, "and that's a job. Who knew?" Once you factor in the possibility of creating your own job in a start-up, the possibilities are not endless, but certainly far greater than you what you know.

My favorite "who knew" moment came on a sunset cruise with my family in Hawaii. The captain wore an open, red plaid vest and a straw cowboy hat, and played Bob Marley as we drank wine and watched the sunset. "And that's a job," I thought. Who knew?

\section{Assumption 2: There is only one thing you can/will be.}

Part of my job as a professor at Fisher is to attend major fairs or meetings with new majors, as well as open houses for prospective students and their parents. One of the most common questions we get is, "What can I do with a major in ----?" One of the most common responses is, "Well, what do you want to be?" Usually the student has only a vague idea or none at all (see assumption 1). But the concern seems to be that a major restricts your career options and/or will close doors to other careers. This can be especially daunting for those who don't know what they want to be.

In reality, only half of college graduates find themselves in a job that is "closely related" to their major; 20\% in a completely unrelated one (Robst, 2007; CareerBuilder, 2013). Economists at the Bureau of Labor Statistics have found that Baby Boomers with college degrees, on average, held nearly 12 different jobs between the ages of 18 and 48 (Bureau of Labor Statistics, 2015). While this number might be greater or less for Millennials, it still means multiple jobs. In other words, you are likely going to work multiple jobs, whether they are in the process of "bouncing around" trying to figure out what you like, or working your way toward a "dream" job. The chances of you finding a job that maximizes your happiness right out of college are not impossible, but not overly probable. 
Even if you are psychologically comfortable with the idea of holding multiple jobs, there may still be the common problem of not having a single "dream" job. Instead, you have lots of things that seem interesting and that would find rewarding. Emilie Wapnick recently gave a TED talk about this idea, calling such people "multipotentialites." She points out that during the Renaissance it was actually desirable to hold and pursue many interests at the same time.

Today, unfortunately, we live in an era of specialization, which is a fairly hostile environment for multipotentialites. We act as if there is a job - a perfect job - for everyone. Indeed, this ideal job is supposedly one that doesn't even feel like work; the lucky ones who find their calling spend most of their waking hours "playing." This perspective puts a tremendous amount of pressure on our work to deliver the goods.

To be fair, most of us will spend roughly half our waking hours at work: Gallup recently reported that the average work week is 47, not 40, hours; nearly a fifth of people work 60 hours or more a week (Saad, 2014). It isn't excessive to ask that we be happy - or at least not miserable - if we are going to be spending that much time at something.

It is excessive, however, to ask that this job provide you everything you want and need in life. Again, a small minority will find this and truly, that is wonderful. But for the rest of us, work will, at the end of the day, remain work. There will be good days and bad days, promotions, great colleagues, long hours, and stress. The trick is to find what is most rewarding to you, for now. In all likelihood it will take you a while in the "real world" to figure it out. And some people never figure it out. But it's only tragic when it's because they didn't try.

For the record, I was an English major. In college I applied for a Naval scholarship that would have required 4 years of service after graduation, but was not accepted. As a result, I signed up to teach English in France but wound up living at home, embroiled in a civil suit (the company was fraudulent) and working at the Kroger deli instead. I seriously entertained becoming a massage therapist before applying to graduate school. I also have no idea where I will be in 10 years, but right now I have a great job that pays the bills. But it took me a while to get here.

\section{Assumption 3: There is a point at which you are an adult who has it all figured out.}

I simultaneously think this idea is great and terrible. It's great because, well, you have it all figured it out. It's also terrible because grown-ups are terrible. Believe me, I've met a few some were "old," but others were fairly young. They don't believe in the impossible anymore, and they can't see the absurdity that is life sometimes. Everything is so serious, and they make me sad inside. 
These people are the exceptions. Most people I know are making it up as they go along. Don't just believe me - ask anyone who by societal standards would be considered an "adult." Ask one when was the last time she or he did something stupid or embarrassed oneself. Ask one how confident they felt they knew what they were doing when they became a parent for the first time. Ask one whether they have it all figured out.

With some mild editing to bring the parental rating down, I leave you with a bit from Joe Rogan's stand-up special I'm Going to Be Dead Someday, which perfectly captures this notion:

"Here's the craziest thing about life. Here's the thing that nobody really considers. You know as much about what life is all about as anybody who has ever lived, ever... We're all just kind of wandering through this, going 'You know what you're doing?' 'Yes.' 'Oh, I do, too. I know what I'm doing.' 'Okay, good then.' Really, no one has a clue. But no one ever brings it up. Remember when you were a kid and you thought there were real grown-ups? ... You were crying, you got sent to your room, and you said to yourself, 'You know what? One day I'm going to be a grown-up and everything's going to make sense!' Then one day you're like 25 at the supermarket and the bag boy calls you 'sir.' ... You mean I'm a grown-up? Are we **!"

\section{References}

Bureau of Labor Statistics. (March 31, 2015). "Number of Jobs Held, Labor Market Activity, and Earnings Growth Among the Youngest Baby Boomers: Results from a Longitudinal Study." Available online at http://www.bls.gov/news.release/pdf/nlsoy.pdf

CareerBuilder. (November 14, 2013). "One-Third of College-Educated Workers Do Not Work in Occupations Related to Their College Major." Available online at http://www.careerbuilder.com/share/aboutus/pressreleasesdetail.aspx?sd=11\%2f14\% $2 f 2013 \&$ siteid=cbpr\&sc_cmp1=cb_pr790_\&id=pr790\&ed=12\%2f31\%2f2013

Robst, John. (2007). "Education and Job Match: The Relatedness of College Major and Work." Economics of Education Review, 26, 397-407.

Saad, Lydia. (August 29, 2014). The '40-Hour’ Workweek Is Actually Longer - by Seven Hours. Gallup. Available online at http://www.gallup.com/poll/175286/hour-workweekactually-longer-seven-hours.aspx

Kathleen Donovan is an assistant professor of political science at St. John Fisher College. She teaches courses in American politics, political behavior, and statistics. In her free time she enjoys sailing, yoga, and trying to "figure it all out." 